\title{
Iglesia y centro parroquial de San Jorge, Pamplona
}

\author{
Saint George's church and parish complex in Pamplona
}

Fernando Tabuenca González y Jesús Leache Resano

https://doi.org/10.17979/aarc.2009.2.1.5039

\section{JESÚS LEACHE: EL PROYECTO}

Ante todo, gracias por la invitación, tanto al Arzobispado como al Colegio de Arquitectos, en esta simbiosis que resulta ejemplar y a la cual deseamos larga vida. Pienso que este tipo de iniciativas debería ser imitado en el resto de España.

Fernando y yo tenemos en Pamplona un pequeño estudio, casi como un taller. Llevamos asociados desde el año 1992, aunque realmente trabajamos juntos desde mucho tiempo antes, afanados en proyectos de los cuales casi el noventa por ciento es obra pública en general o resultado de concursos. Dentro de esa obra pública hoy presentamos esta iglesia, que para nosotros ha sido el primer ejercicio de arquitectura religiosa de nuestra carrera profesional.

Esta iglesia, situada en Pamplona, es fruto de un concurso promovido por el Arzobispado de Pamplona y Tudela, en un momento del año 2000 donde renació esta política plausible de concursos para obtener edificios religiosos de cierta relevancia y con interés. Y como la historia nos ha enseñado, es la mejor fórmula para obtener resultados óptimos (Fig. 01). Fue un concurso convocado con unas bases claras y sensatas, con un jurado conocido y solvente, con unas condiciones razonables y con una absoluta naturalidad. Digo esto porque el pliego del concurso para hacer esta iglesia que no es un edificio ni sencillo ni pequeño - serían unos diez folios, frente a otros concursos a los que estamos habituados, promovidos por la Administración, que tienen ciento cincuenta folios, y que realmente, cuando terminas el concurso todavía no has acabado de entender el pliego de condiciones. Con ello quiero animar a la curia eclesiástica a que continúe con esta política — que la rescate-, porque pensamos que es la mejor herramienta para hacer crecer el patrimonio de la arquitectura religiosa en nuestro país.

El programa que se nos pedía era una iglesia parroquial: un templo con una capacidad para cuatrocientas personas y una capilla de diario para cien personas. A su vez, un centro parroquial que dispusiera de salas para diversos usos, así como los despachos y las salas de catequesis necesarias en este tipo de conjuntos. El programa era una cosa muy sencilla, muy clara. Nos presentamos y nos pusimos a ello.

$Y$ en cuanto al emplazamiento, el solar sobre el cual se debería construir la iglesia se situaba en un barrio periférico (Fig. 02). En Pamplona, algunos barrios de la vega del río Arga han estado degradados hasta hace poco tiempo, pero que gracias a una inversión importante de fondos estructurales europeos, se han ido recuperando a lo largo de estos quince últimos años. Así, el río ha sido redescubierto y se ha incorporado al paisaje urbano como parque lineal, como un activo importantísimo. Les invito a que conozcan Pamplona, porque aun- 


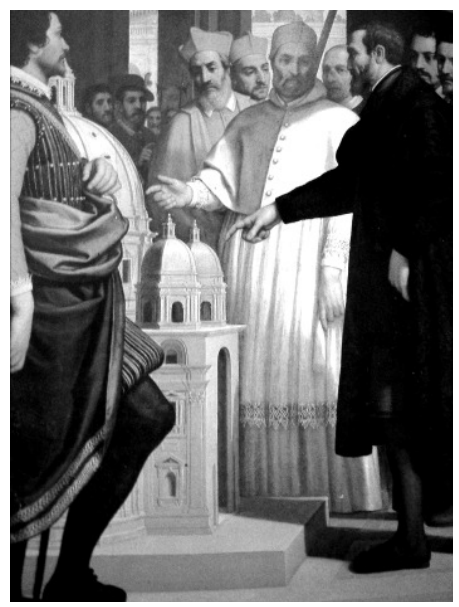

Fig. 1. Domenico Cresti da Passignano, Miguel Ángel entrega la maqueta de San Pedro a Julio II (1619).

que es una ciudad que tiene menos piedras que Ourense, es una ciudad con un urbanismo bastante aseado que merece la pena ser visto.

Dentro de este barrio de San Jorge, el área que rodea el solar es de nueva construcción. Por la zona norte cruzan las vías del tren, que en el futuro desaparecerán. Justo detrás del solar hay un gran edificio lineal que acompaña a un paseo peatonal, y una serie de edificios perpendiculares a la avenida principal del barrio. Todo este plan fue proyectado por los técnicos del Ayuntamiento de Pamplona de una forma intencionada, higienicista, buscando un cierto orden pero con resultados que en algunos casos pueden resultar dudosos. Se trataba de una iglesia que el barrio esperaba desde hacía treinta años, y que había sufrido numerosos retrasos y numerosas vicisitudes. Entre otras cosas, se había redactado un proyecto anterior, que no prosperó y se quedó en la estantería. Hasta ahora las celebraciones se realizaban en un local bajo unas viviendas, como ocurre tantas veces.

Todo esto se hizo - quiero decirlo - bajo el mandato de don Fernando Sebastián, Arzobispo de Pamplona, con quién tuvimos ocasión de entrevistarnos en dos o tres ocasiones, y que solamente con su mirada y con su presencia subrayó la importancia que debía tener esa actuación.

Con lo cual, ese era el emplazamiento. Recordarán

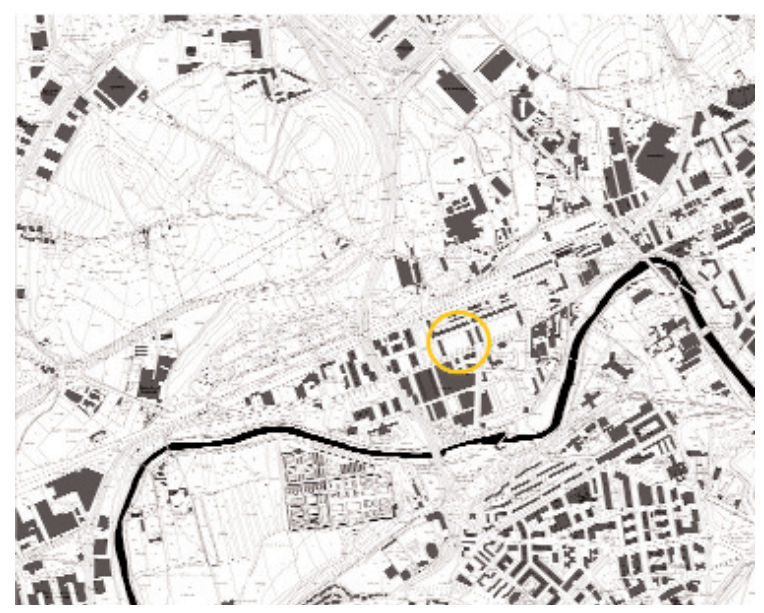

Fig. 2. Pamplona; emplazamiento de la iglesia de San Jorge.

el cuadro de La Ciudad Ideal de Piero della Francesca, donde aparece el edificio redondo en el centro, con unas casas alrededor (Fig. 03). Pues aquí nos encontramos con que esas casas se habían convertido en esas arquitecturas, por llamarlas de alguna forma, de seis y ocho plantas, con estas logias en la coronación, en fin... daban ganas de salir corriendo. Hay un pequeño gesto, un eje que conecta con la nada prácticamente, y un porche, aunque solo sea por aquello de huir de la lluvia, que por lo menos le da una cierta escala y amabilidad. Se llegó a un acuerdo entre el Arzobispado y el Ayuntamiento sobre la previsión del planeamiento urbano, y dónde debería ir esa dotación, que ya se sabía que iba a ser la iglesia del barrio. Bien, pues ésta era la situación que nos encontramos.

A partir de ahí nos pusimos a trabajar. Y lo primero que hicimos fue proponernos cumplir las bases del concurso, planteando aquello de que si no puedes con el enemigo, alíate con él. Realmente, las ubicaciones urbanísticas supusieron para nosotros la apoyatura y la piedra angular para poder trabajar. En definitiva, lo que nos planteábamos era someternos a las reglas de juego de la trama urbana, someternos a ella como uno más, y con este desplazamiento respecto al planeamiento propuesto, crear una calle y una plaza presidida por una iglesia. Huyendo de formas orgánicas extrañas, autistas —no me gusta decir esta palabra-, y de alguna forma, 


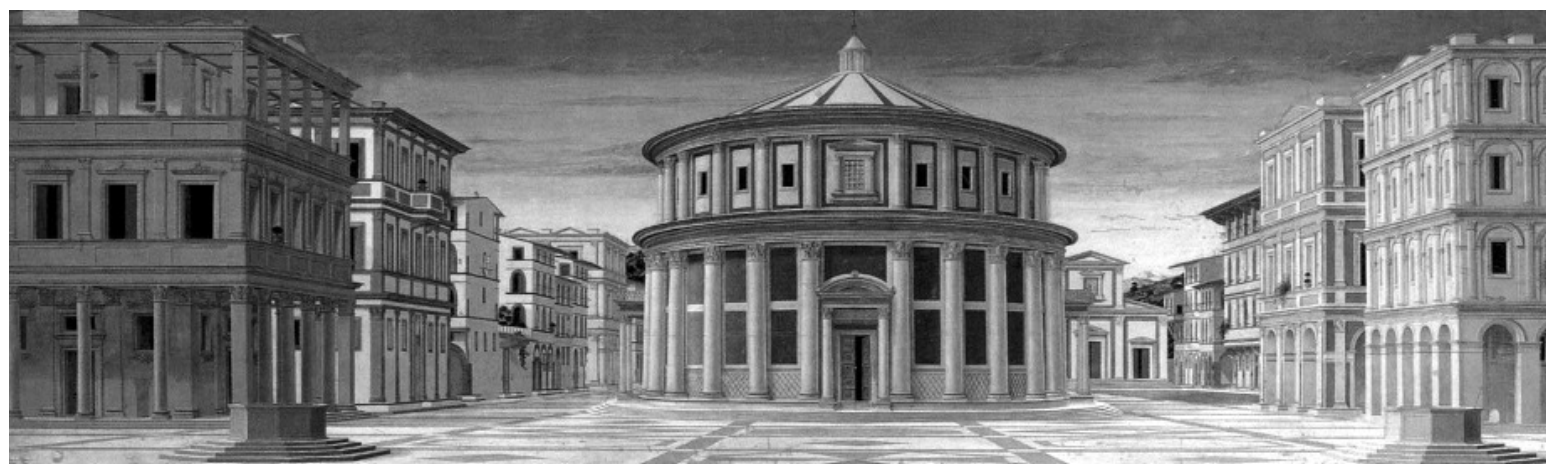

Fig. 3. Piero della Francesca, La ciudad ideal (h. 1475).
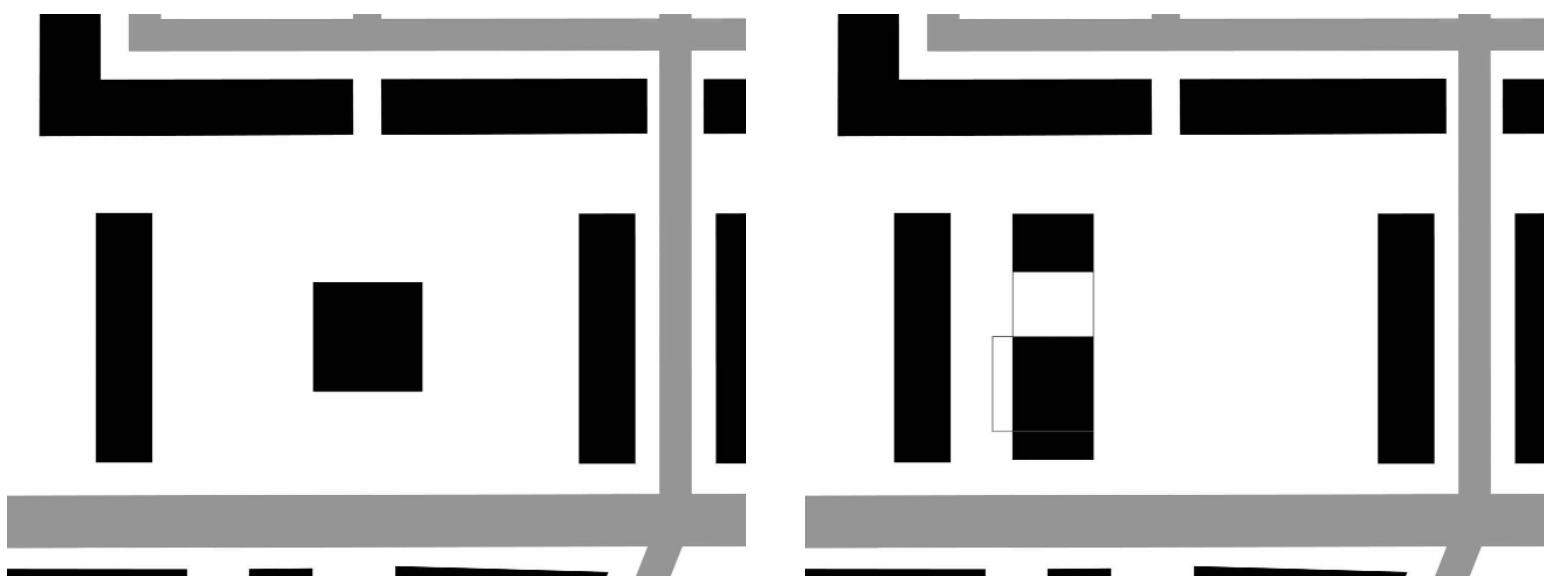

Fig. 6. Situación de la iglesia prevista por el ayuntamiento vs. situación de la iglesia planteada en el proyecto vencedor del concurso

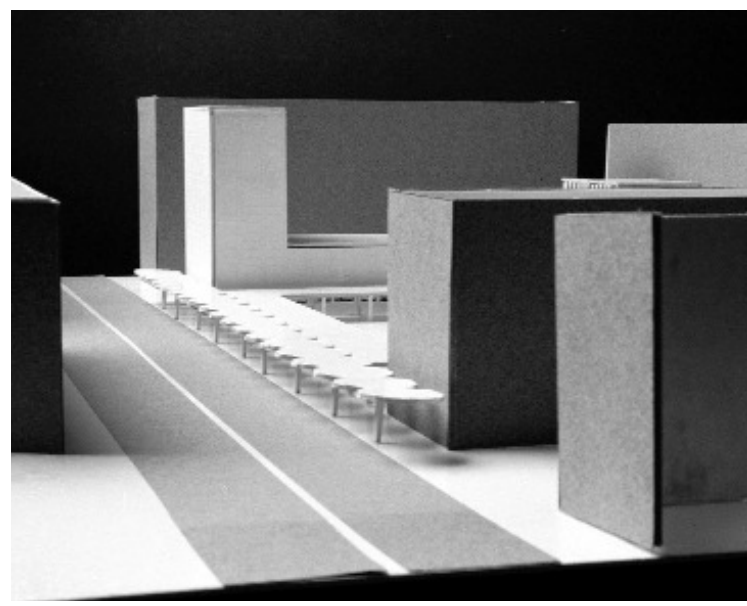

Fig. 4. Detalle de la maqueta del concurso (2000); vista desde la avenida.

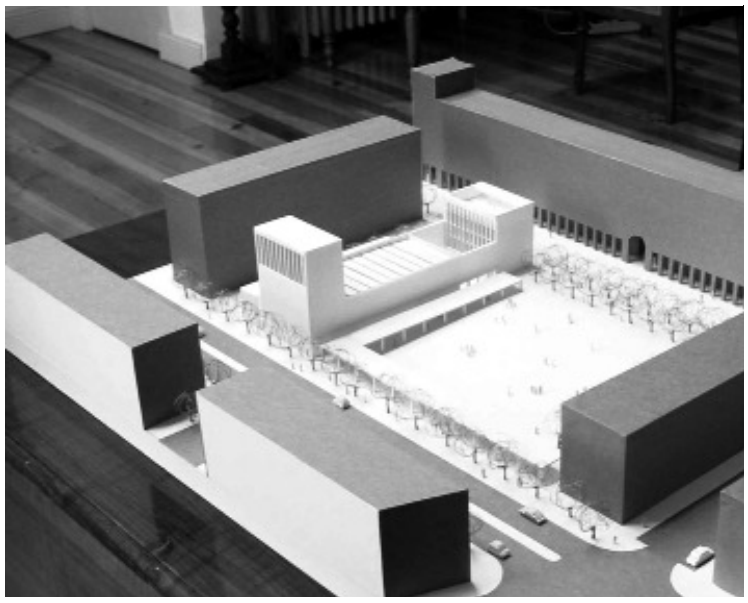

Fig. 5. La maqueta del concurso, en el despacho del Arzobispo de Pamplona (2000/02). 
apoyándonos en lo que existía.

Esteban [Fernández-Cobián] nos decía: podéis mostrar algunas de las referencias que tenéis, sobre las que hacéis vuestro trabajo. Hubiéramos podido traer aquí iglesias fantásticas de Miguel Fisac, que por supuesto nos hubiera gustado que nos hubiera influido, como nos hubiera gustado que nos hubieran influido Paladio, Gil de Ontañón y también Peter Zumthor... Pero para competir con ese entorno construido, a nosotros solamente nos venían a la cabeza imágenes que por su abstracción, por su potencia o por su estructura aportaran un contrapunto a lo que le rodeaba: esas ventanas y esos tendederos a tan poca distancia de la iglesia.

En la propuesta del concurso, planteamos un volumen esculpido con una gran torre que, como el resto de los edificios la avenida principal, sacaba pecho (Fig. 04). De alguna forma recuperábamos un elemento importante -icónico, clásico, tradicional- de las iglesias, como es la cruz. Y a su vez, la iglesia intentaba hacer ciudad, aglutinar a la comunidad, crear su plaza, en fin, cosas todas ellas que están en la tradición de la arquitectura religiosa. Trabajamos sobre el asunto dándole mil vueltas a distintas proporciones, estradas de luz, etc., hasta que llegamos a un momento de crisis, porque la maqueta de presentación ante don Fernando les encantó, les pareció maravillosa, pero se quedó en la mesa del Arzobispo descansando el sueño de los justos (Fig. 05). El Ayuntamiento no aceptó la posibilidad de desplazar el volumen construido por las posibles protestas que pudiera haber de los vecinos de estas viviendas (cosa que la vimos un poco cogida por los pelos). Fue un proceso de unos dos años, más o menos (Fig. 06).

A partir de aquí reconsideramos la situación. Sacamos otra vez el plano de este bonito planeamiento y comenzamos a repensar el asunto. Por nuestro imaginario pasó toda la historia de la arquitectura: otras alternativas, tentativas de espacio central, etc. No sabíamos hacia dónde ir. Después de luchas, zozobras y sudores, dijimos: - Vamos a ser buenos chicos y a empezar de cero. Retomamos esa idea de la planta central, y puesto que después de muchas discusiones, al Arzobispado le había agradado el planteamiento de la iglesia inicial, dijimos: - Vamos a ver qué pasa si exportamos esa iglesia al centro de la plaza. Dispusimos el templo junto a la avenida, y la casa parroquial junto al paseo; y entre los dos crearon este espacio, que nosotros acotamos con
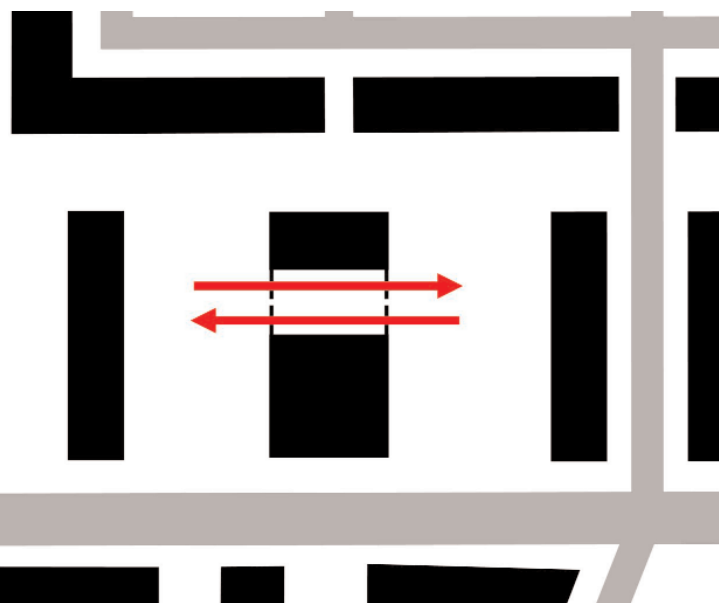

Fig. 7. Situación final de la iglesia, con el atrio abierto a la plaza del barrio.

unos brazos formando un atrio que los cosiera y que a su vez, permitiera algo que para nosotros era la patata caliente del proyecto: la circulación a través del edificio (Fig. 07). Se creaba así un espacio grato, no agresivo; un espacio también accesible para el ateo mas radical, que quizá un día dice voy a entrar, y que a su vez, es un foco de atracción y de encuentro para todo el barrio.

Nos venían a la mente atrios históricos; lugares maravillosos, fantásticos, de recogimiento, de preparación al culto y de aislamiento, en nuestro caso respecto a una edificación circundante que ayuda a cualquier cosa menos a la oración, a la contemplación, a la meditación y al encuentro religioso. A partir de ahí desarrollamos el proyecto. El atrio conector queda abierto los días de celebración para su uso permanente. Nosotros, en el proyecto, lo propusimos sin puertas; pero por una cuestión de seguridad nocturna, acabaron apareciendo unas celosías.

Mediante maquetas de trabajo empezamos también a trabajar sobre la luz y sobre la instalación de los elementos litúrgicos. Una luz entra sobre el presbiterio y baña la mesa del altar, y otra luz — más difusa, más tenue - entra a través de la vidriera y baña la zona de los fieles. En la sección longitudinal es donde está la madre del cordero, donde todo ello está cosido buscando una idea que nos parecía fundamental: frente a esa 


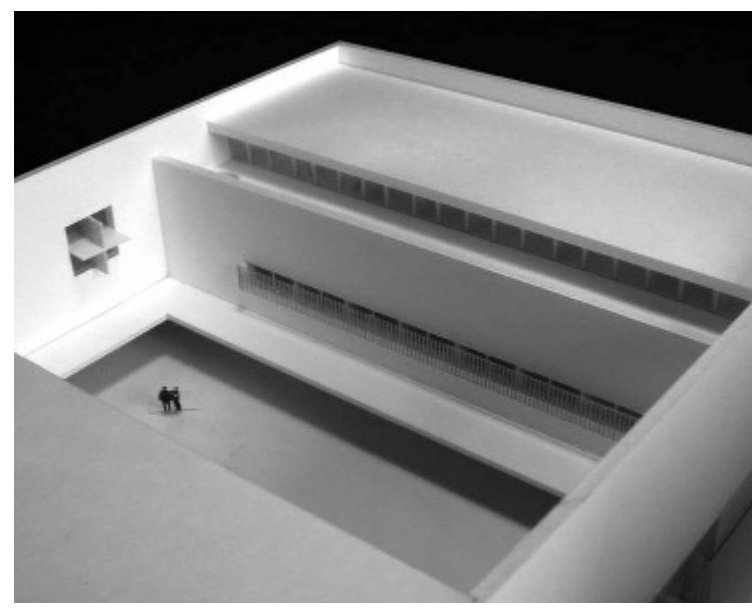

Fig. 10. Maqueta del concurso (2000); vista del atrio hacia el centro parroquial.

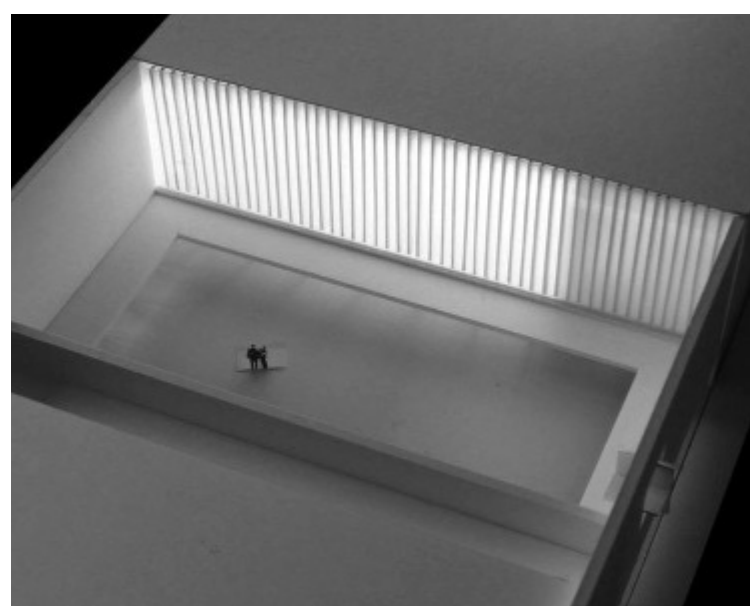

Fig. 11. Maqueta del concurso (2000); vista del atrio hacia la iglesia.

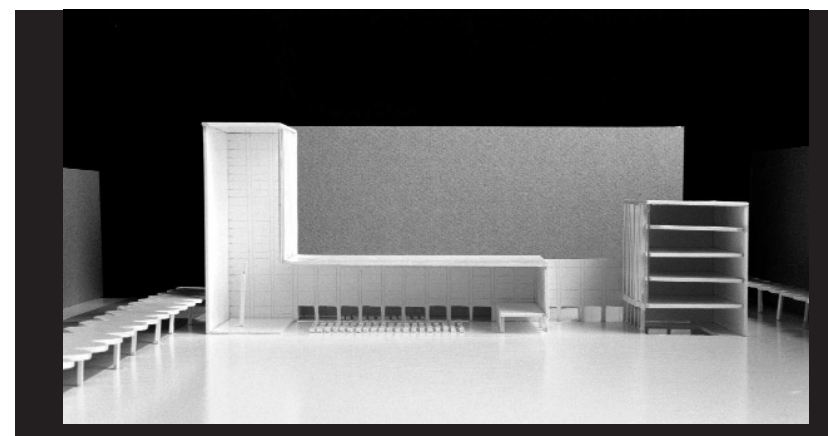

Fig. 8. Maqueta del concurso (2000); sección longitudinal.

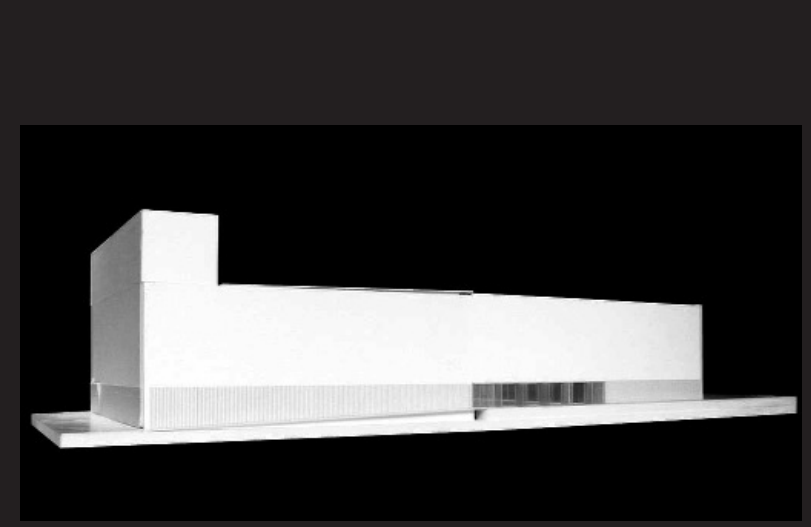

Fig. 9. Maqueta del concurso (2000); alzado éste.

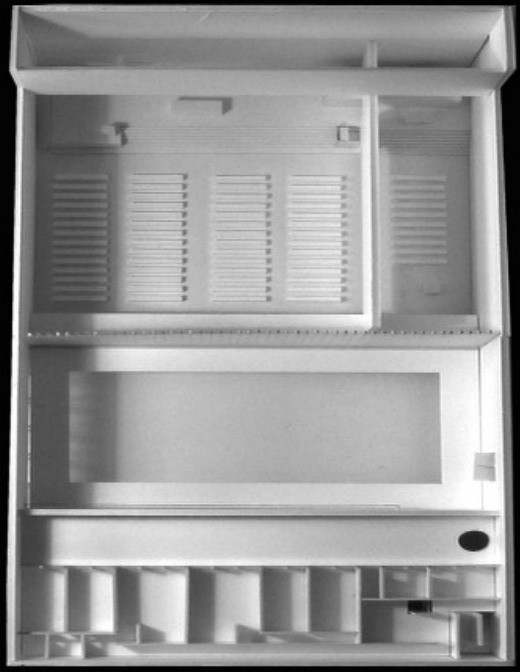

Fig. 12. Maqueta del concurso (2000); vista de pájaro. 


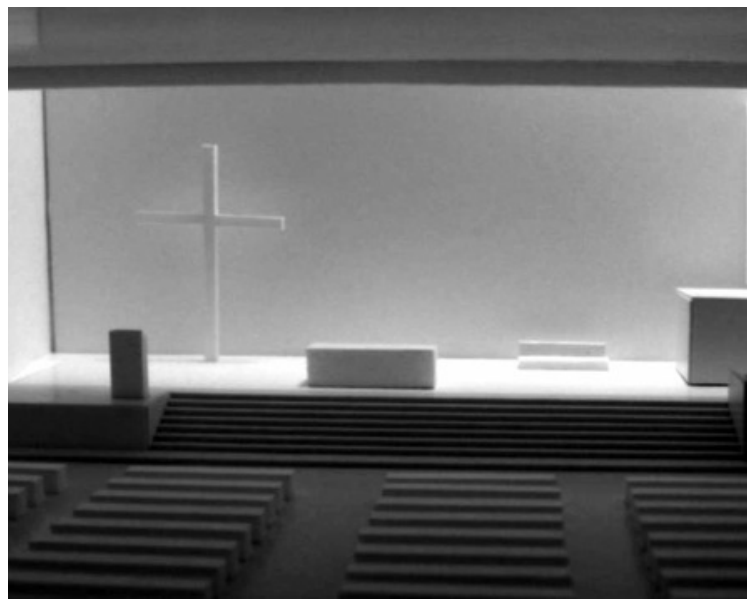

Fig. 13. Maqueta del concurso (2000); vista del presbiterio.

imagen de las viviendas circundantes tan poco vistosa, crear un edificio absolutamente unitario que no tuviera ninguna fisura, ni filosófica ni de las otras; y frente a esos proyectos fragmentarios donde el templo en una cosa y la casa del cura es otra - y siempre hay problemas con la escala de las ventanitas-, unir las tres piezas para darle al edificio una escala más potente (Fig. 08 y 09 ).

Por eso los despachos parroquiales se vuelcan hacia el atrio, quedando en contacto visual con la gente que transita por él: salas multiusos, salas de talleres, de catequesis para los niños; viviendas del párroco y de sus ayudantes que se subrogan al orden general, cuya iluminación y ventilación se produce a través de una terraza sin vistas pero perfectamente iluminada (Fig. 10). Con lo cual, esa escala menuda, doméstica, que es antitética con la escala de la casa de Dios - aunque las dos son casas, hay una que es claramente mas importante que la otra-, no produce esa competencia que a veces se puede llegar a producir.

El atrio lo modulamos con un patrón muy claro de tres metros que nos ayudó mucho, porque permitió absorber todos los cambios que nos fueron exigiendo desde la propiedad, el Ayuntamiento, el CTE, etc. Y ya se sabe que a quien modula Dios le ayuda. A través del atrio se entra a la iglesia por un filtro que estaba pensado para que los niños que se portasen mal se quedaran

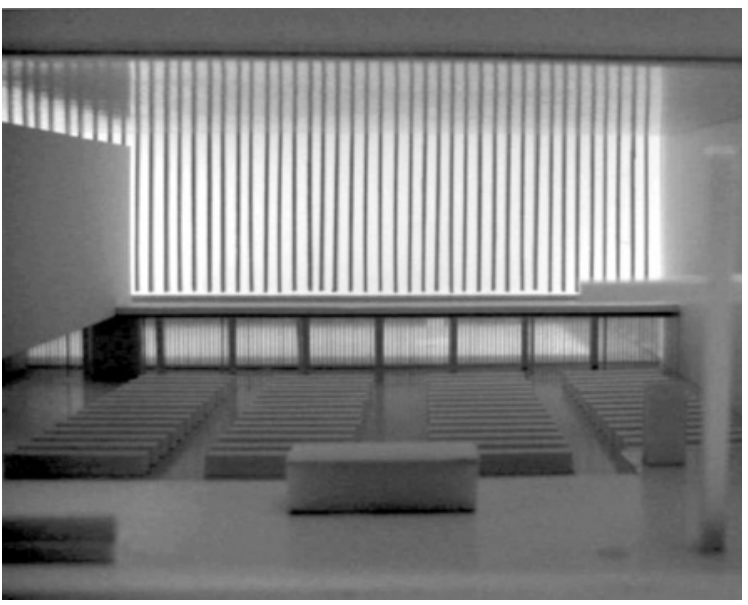

Fig. 14. Maqueta del concurso (2000); vista de la nave desde el presbiterio.

aquí. Pero bueno, aunque no haya niños también sirve de doble filtro acústico y de filtro de cambio, un poco como sitio para dejar el paraguas, porque el atrio tiene un voladizo que protege de la lluvia en todo su perímetro, y el resto está abierto (Fig. 11).

A partir de aquí accedemos al templo (Fig. 12). Es prácticamente un cuadrado, dividido por una gran vigapantalla que separa la capilla de diario - que estaba dentro del programa de necesidades - de la nave principal. Mediante unos estores ligeros que se levantan los domingos, todos los fieles pueden participar de la misa que se celebra en el altar principal. Desde la entrada de la capilla de diario, se accede a la mini capilla confesional o penitencial. En las reuniones litúrgicas se discutió mucho sobre la pila bautismal, porque en la tradición reciente de Pamplona, muchas de ellas aparecían en el presbiterio para facilitar la celebración del bautismo. Pero si a nosotros ya nos había costado colocar cuatro cosas, nos resultaba dificilísimo meter una quinta... Es fácil distinguir en el presbiterio el altar, el ambón y la sede. La sacristía es un volumen que atraviesa esta pantalla y que está a caballo entre ambas aulas, y en el cual se empotra el sagrario. La sacristía comparte la luz natural del lucernario del presbiterio (Fig. 13 y 14).

Como ven, la sección transversal es muy sencilla. Con esta gran pantalla obteníamos dos arquitecturas, 


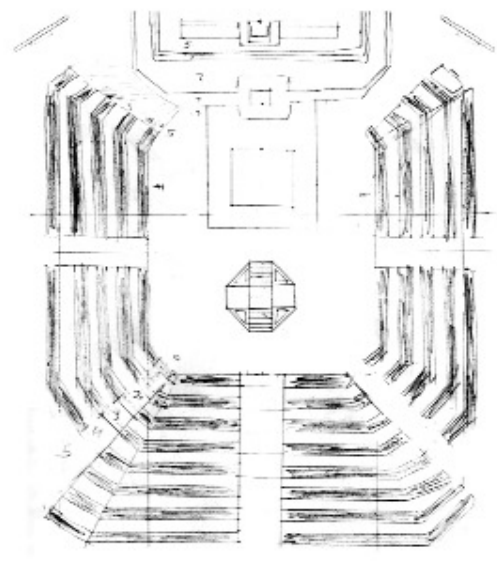

Fig. 15. Propuesta del nuevo párroco para la adecuación litúrgica de la nave (2004).

una preconciliar y otra postconciliar... Bueno, esto que digo en broma, en realidad es un ejercicio interesante, porque la emoción del espacio pequeño y su intensidad es, permítaseme, mas preconciliar, pues es distinta del espacio grande, que no deja de tenerla, pero que, en fin, tiene otras características. Y todo esto siempre sobre un esquema cuadrado, al cual segregamos un rectángulo para hacer la nave lateral, segregamos un rectángulo para hacer el lucernario, y segregamos otros dos rectángulos para hacer el atrio y el centro parroquial.

El proyecto les encantó: ¡Nos parece maravilloso, nos encanta, qué buen proyecto! Y cuando ya está el proyecto de ejecución en su carpeta, entregado, ¡nos dicen que le tenemos que rebajar un veinte por ciento del presupuesto! Hubo que repensar las cubiertas.

Y hubo otra crisis más. Porque con todo ya visado, con todos los presupuestos corregidos, con todas las estructuras calculadas, con todas las normativas cumplidas, con todo, todo, todo terminado, aparece un párroco nuevo, tan maravilloso y encantador como el anterior. Porque el anterior, don Mario, era una persona encantadora, y don Juan Arnáez no lo es menos. Y con toda su buena voluntad nos propone otro modelo de iglesia... Y nos manda por fax un escrito diciendo: «¿Y si nos planteáramos algo de este tipo?» (Fig. 15). Así que ¡crisis total! Ayer se habló aquí, en la mesa redonda, de flexibilidad, de los espacios excluyentes o incluyentes. Realmente lo que dijimos fue que nosotros estábamos dispuestos — con nuestro entusiasmo, con nuestro esfuerzo - a trabajar sobre este esquema, pero que esto suponía hacer otro proyecto. Estaríamos encantados de hacerlo y de empezar desde cero, pero nos gustaría que supiera que no podíamos integrar esa luz, esa imagen, esa vidriera con el esquema que nos sugería. El espacio que proponía era absolutamente antitético con nuestra organización: jabsolutamente! Esa pila bautismal por inmersión central que yo había visto en las iglesias de alguna comunidad neocatecumenal... Bien, ellos tienen su organización litúrgica, pero claro, es muy específica. Y esto no estaba en el programa. Lo entendieron perfectamente, se obvió, se asumió gustosamente el templo proyectado y finalmente se pudo construir. Y nos alegramos que a don Juan Arnáez le hayan ascendido a Vicario, lo cual significa que las cosas no le han ido tan mal, ¿no?. Cedo la palabra a Fernando.

\section{FERNANDO TABUENCA: LA CONSTRUCCIÓN}

Muchas gracias. Voy a explicar algunas imágenes de la construcción de la obra, y finalmente, de la obra ya terminada.

Uno de los grandes problemas en un edificio esencialmente introvertido como éste, era la construcción de los muros. Decidimos utilizar un único material, el hormigón, haciendo alusión a la forma tradicional de la construcción de las grandes iglesias, que también se hacía con un único material, la piedra. Considerábamos que quizá el hormigón fuera la piedra contemporánea; y de ahí esta elección, que permitía una construcción sólida, relativamente rápida y hasta cierto punto, económica.

Tuvimos la suerte de contar con VDR, una constructora local que ahora ha conocido una cierta expansión, con una disposición magnífica: unos estupendos encofradores y carpinteros que, tras la realización de una serie de muestras previas en las que se decidió el tipo de hormigón, su cualidad formal y su despiece, nos permitieron que la obra se pudiera ejecutar en un tiempo realmente rápido (Fig. 16).

Partimos de unos elementos prefabricados, a los cuales les fuimos adosando unas piezas de madera que permitían crear diversas texturas. Al encofrado del zócalo se le quiso dar una rugosidad mayor; primero, para darle ese carácter de zócalo desde el punto de vista 

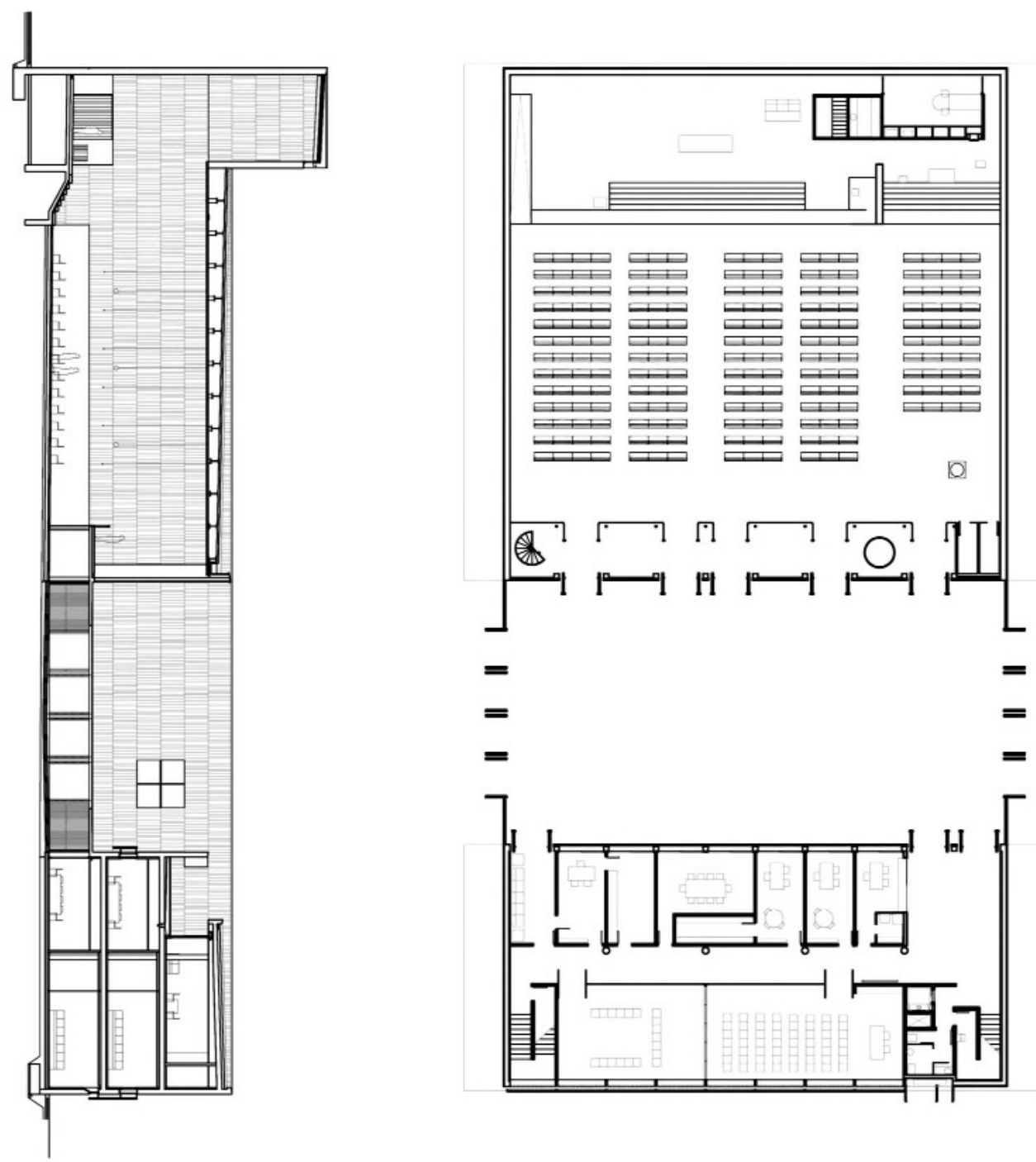

Fig. 16. Iglesia parroquial de San Jorge, Pamplona (2000/08);

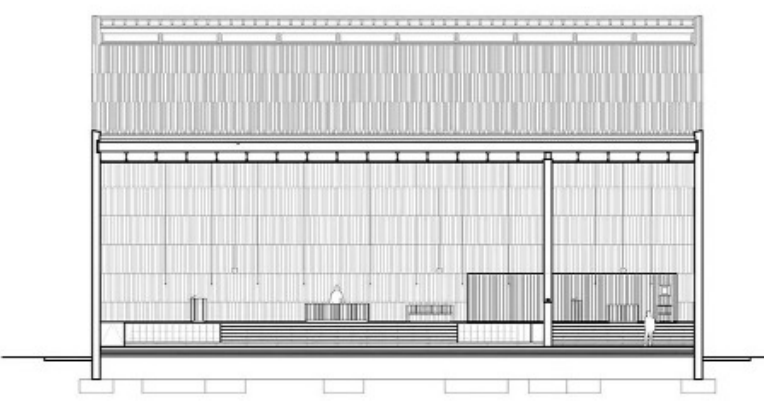
proyecto definitivo. 


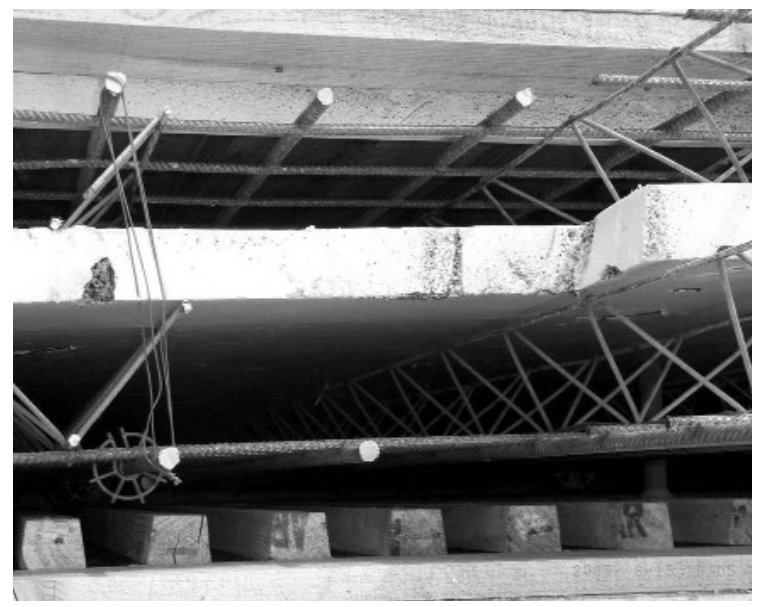

Fig. 17. Detalle constructivo del encofrado de los muros de hormigón armado.

compositivo, y luego, por una razón práctica: intentar evitar las pintadas y la pegada de carteles, que en estos barrios periféricos de la ciudad podía llegar a ser un problema. Afortunadamente, debo decir que no ha habido ningún problema, no sé si gracias a esta solución o porque el civismo de los habitantes del barrio es mucho mayor del que nosotros sospechábamos.

El muro, con un grueso total de cuarenta centímetros, está realizado de una vez, pero en dos hojas, de manera que en medio - previamente al hormigonadose situaba una plancha de aislamiento de poliestireno extrusionado (Fig. 17). Hicimos algunas muestras a escala real para decidir los despieces del zócalo, que se resolvieron disponiendo una serie de tablas de pino sin cepillar - las mas baratas, tal y como salían de la serrería- colocadas de una forma un tanto aleatoria, pero destacando precisamente las diferentes anchuras de esas tablas con un pequeño berenjeno que les daba relieve. De modo que una masa de hormigón tan grande como ésta, al ser bañada por el sol, adquiría una cierta cualidad arquitectónica.

La textura del interior es exactamente igual que la del exterior, para emular la unidad de material y de carácter que tenían las antiguas iglesias de piedra. Debo decir también que, gracias a la magnífica actitud de la empresa constructora, en esta obra se recurrió a un tipo de hormigón autocompactable muy fluido, casi líquido,

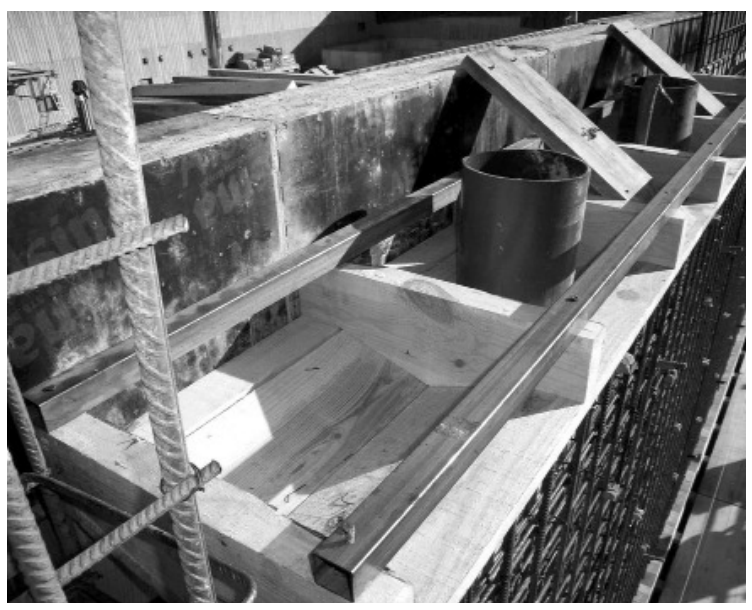

Fig. 18. Detalle de la coronación de los muros de hormigón armado.

que permitió que todos los muros se realizaran con una ejecución casi perfecta, sin ningún tipo de coquera ni de defecto. Sin embargo, eso obligó a construir en la parte superior de la coronación de los muros unos encofrados con una cierta inclinación. Como no era posible darle inclinación al remate del muro - para eso hubiera sido necesario un hormigón mucho mas seco-, de esta manera hacíamos que el agua que pudiera caer desde estos remates finales de muro vertiera siempre hacia el interior, hacia la cubierta, y no hacia el exterior (Fig. 18). Así evitamos en gran medida las manchas sobre el hormigón. Un hormigón que, además, fue tratado con productos protectores e hidrofugantes. También fue necesario prever en los muros algunos nichos para la colocación de distintas instalaciones, como bocas de incendio, colectores para el suelo radiante que después iba a usar la iglesia como sistema de calefacción, refrescamiento, etc.

Unos detalles de la cubierta. Como hemos dicho, tuvimos que recurrir a una solución lo mas económica posible, puesto que esto tenía una repercusión importante en el presupuesto. Son unas vigas metálicas de alma llena que van de lado a lado. Tienen un apoyo intermedio en la viga de separación entre las dos naves. Las vigas que iban a soportar el lucernario del presbiterio están hechas en madera microlaminada - KERTO es la marca comercial- Estas piezas de madera traba- 


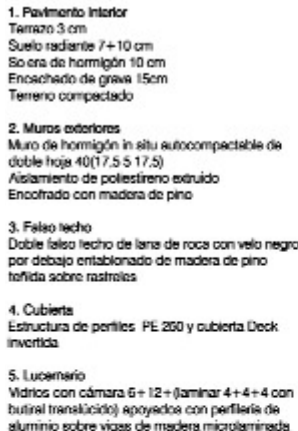

Fig. 19. Sección constructiva por el lucernario. 


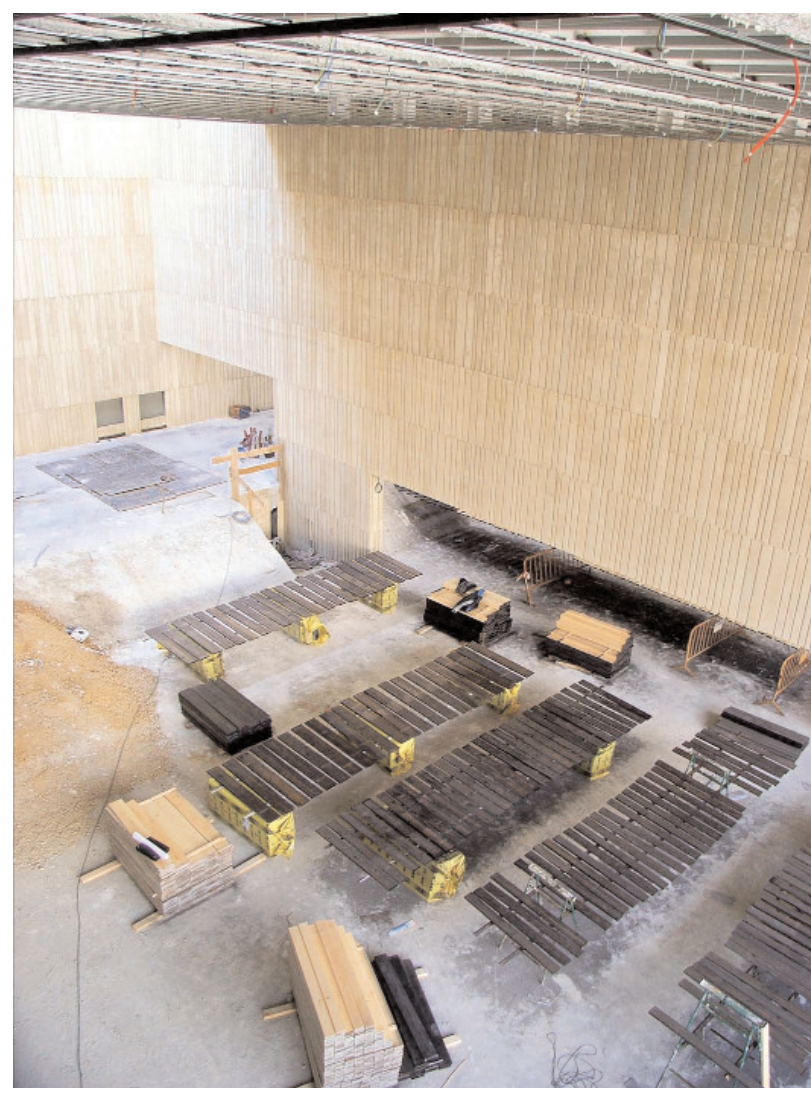

Fig. 20. La nave de la iglesia, durante el montaje del falso techo de madera (2007).

Fig. 22. Detalle de los montantes del muro de alabastro.

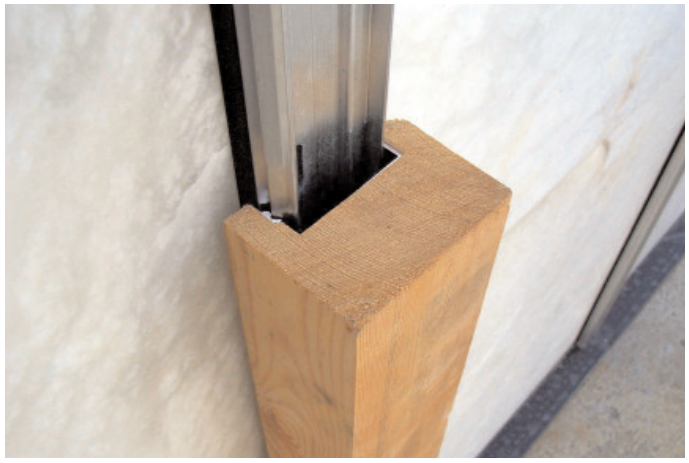

Fig. 21. Montaje del muro de alabastro (2007).

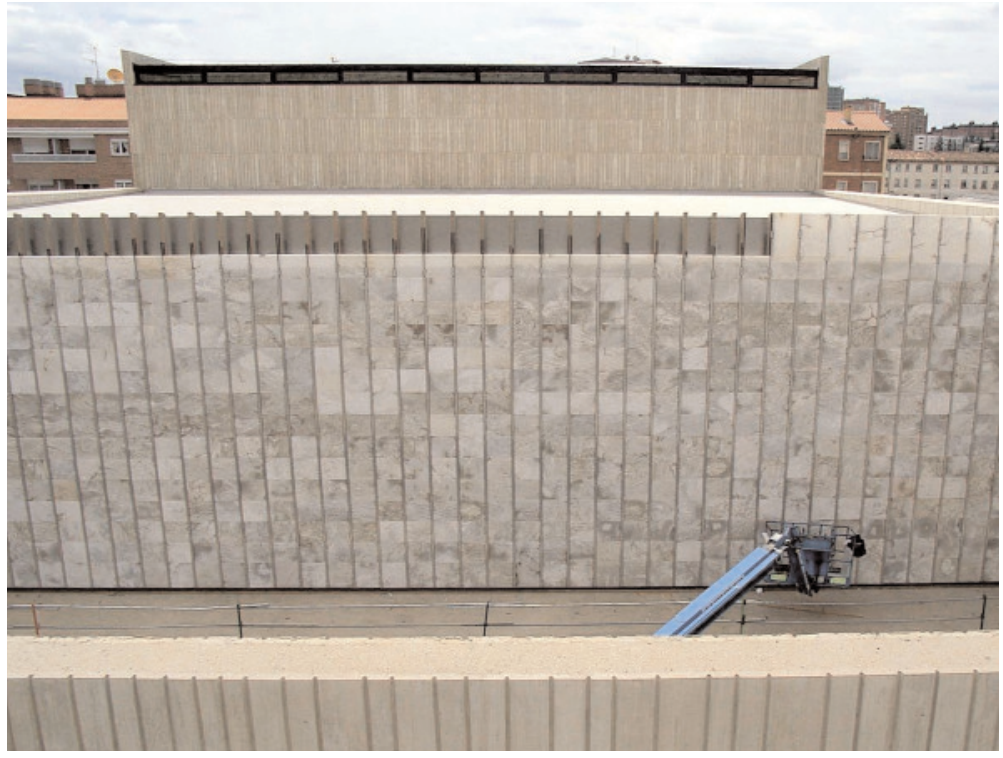


Fig. 23. Vertido del pavimento del atrio (2007).

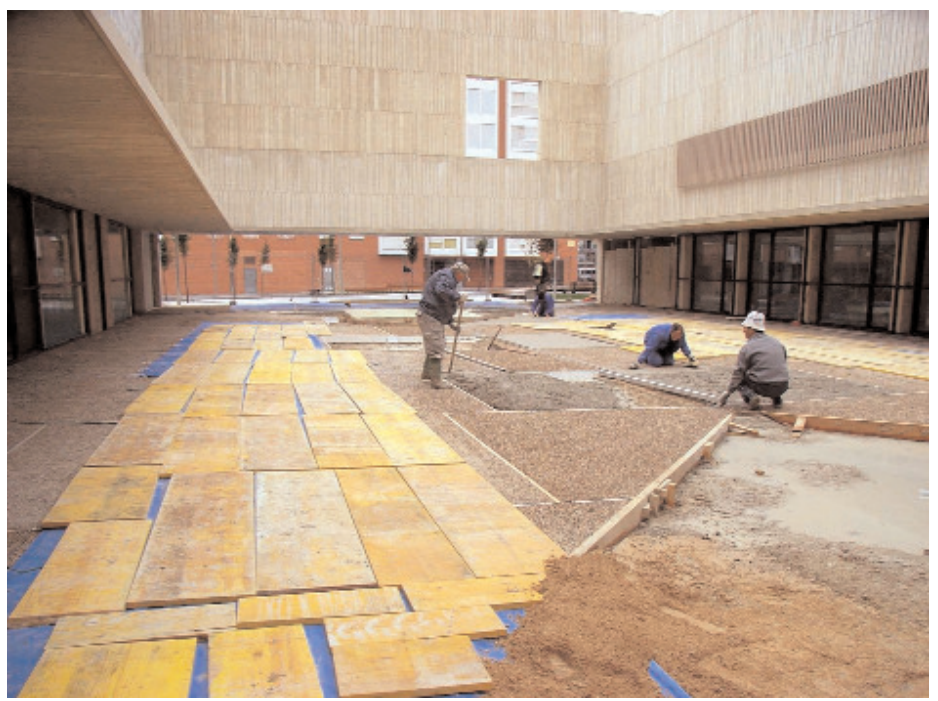

jan como estructura y como soporte de los paños de vidrio. Unos grandes montantes de madera cierran la vidriera que separa la nave principal del atrio; son idénticas a las que se emplearon en el lucernario (Fig. 19). El falso techo se realizó con las mismas piezas de madera con las que se había construido el encofrado de los muros de la nave. Y, así, colocados en el techo con una cierta separación entre ellos y con una lana de roca con un velo negro por encima, crean unas condiciones acústicas suficientemente buenas para el uso de la iglesia; y, de hecho, han funcionado muy bien (Fig. 20).

Aunque a la vidriera exterior le llamamos «vidriera», es casi una solución de muro cortina. Pero nos gusta llamarle así porque de alguna forma equivale al rosetón típico de las iglesias tradicionales. Esto llevó a pensar en la posibilidad de sumarnos también —en una interpretación más literal — a la tradición clásica de los vidrios coloreados. Finalmente nos decidimos a unir con alabastro los espacios entre las piezas verticales de madera (Fig. 21). El alabastro se colocó en piezas pequeñas, de reducido espesor, que era lo más económico. Lo cual, a su vez, resaltó más la condición traslúcida del cerramiento, que permitía una luz atenuada a los pies de la nave que no competía con la luz directa, más importante, que baña el presbiterio. Además, esa luz difusa venía acentuada por el hecho de ser esa la cara norte. El veteado y el diferente grado de trasparen- cia de las piezas de alabastro provocan desde el interior efectos de claroscuro en esa vidriera, que le dan a la fachada una cierta vibración. El elemento sustentante vertical de la vidriera es una pieza de aluminio usada en los muros cortina convencionales, pero utilizando como tapa una pieza de madera (Fig. 22).

En cuanto a los pavimentos, únicamente debo decir que el pavimento del atrio está hecho con un hormigón lavado, con un árido de río en canto rodado que nos daba una coloración ligeramente cálida, parda, que entonaba muy bien con el tono de los muros de la iglesia (Fig. 23). Por su parte, el pavimento interior, tanto el del centro parroquial como el de las dos naves, está realizado con un terrazo oscuro, sencillísimo y baratísimo. La única particularidad es que la composición de ese terrazo - su composición y su granulometría - se la dimos nosotros al fabricante; no era un color habitual, de manera que había que encargar muchos metros cuadrados. Pero no hubo ningún problema en hacer un terrazo a la medida, con el color y el grano deseado (Fig. 24).

Por último los elementos litúrgicos. Realizamos una maqueta a tamaño 1:1, en la cual los obreros se prestaron a aparecer como figurantes. En ese montaje previo, los elementos litúrgicos fueron construidos en madera por los propios carpinteros de toda la obra. El altar se realizó también en hormigón, con las mismas tablas de madera con las que se había construido todo el edificio. El transporte y la colocación del altar tuvieron su miga, 
FERNANDO TABUENCA GONZÁLEZ Y JESÚS LEACHE RESANO

Fig. 24. Vista interior de la nave, con el pavimento de terrazo continuo terminado (2008).

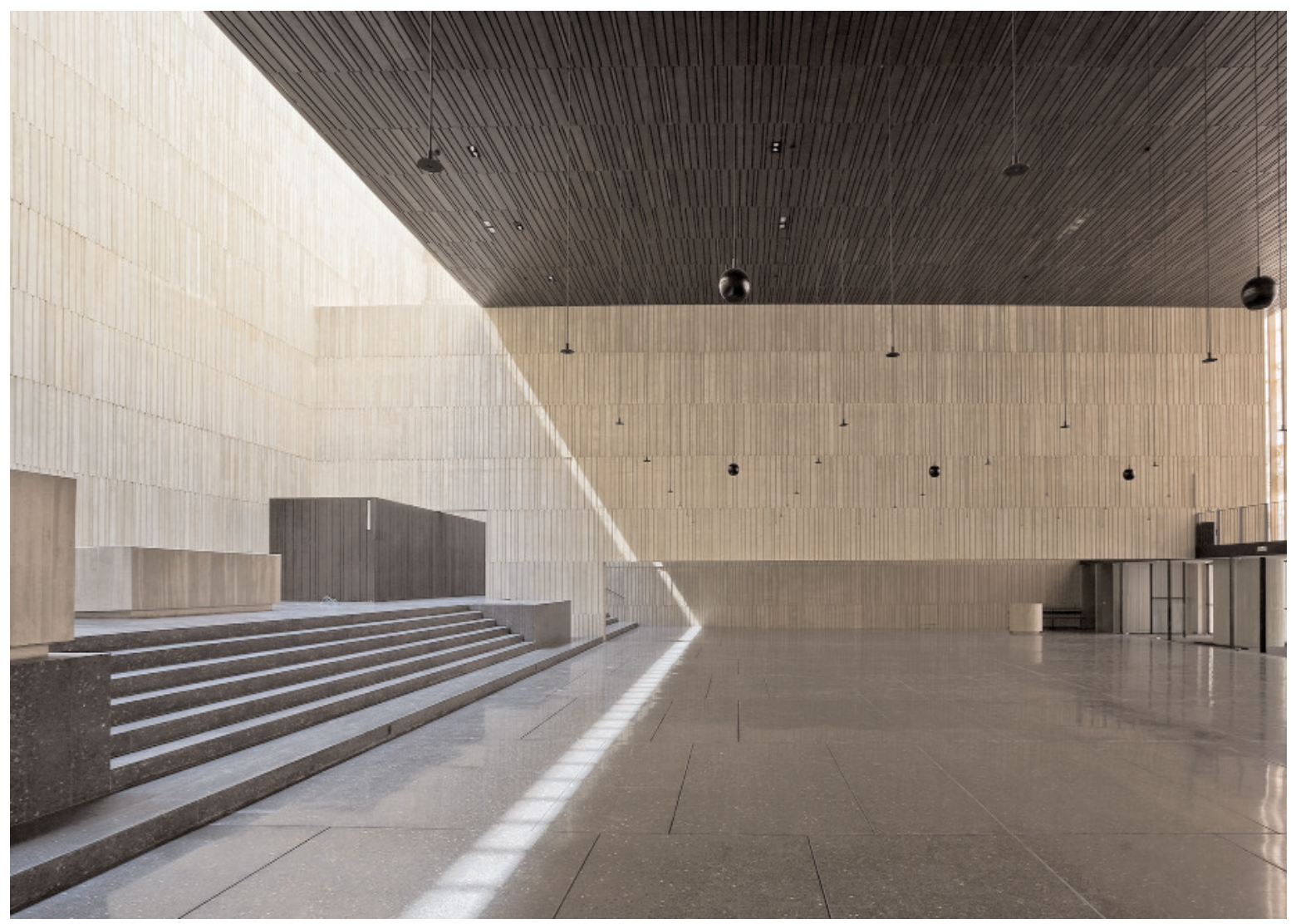


Fig. 25. Desencofrado del altar (2008).

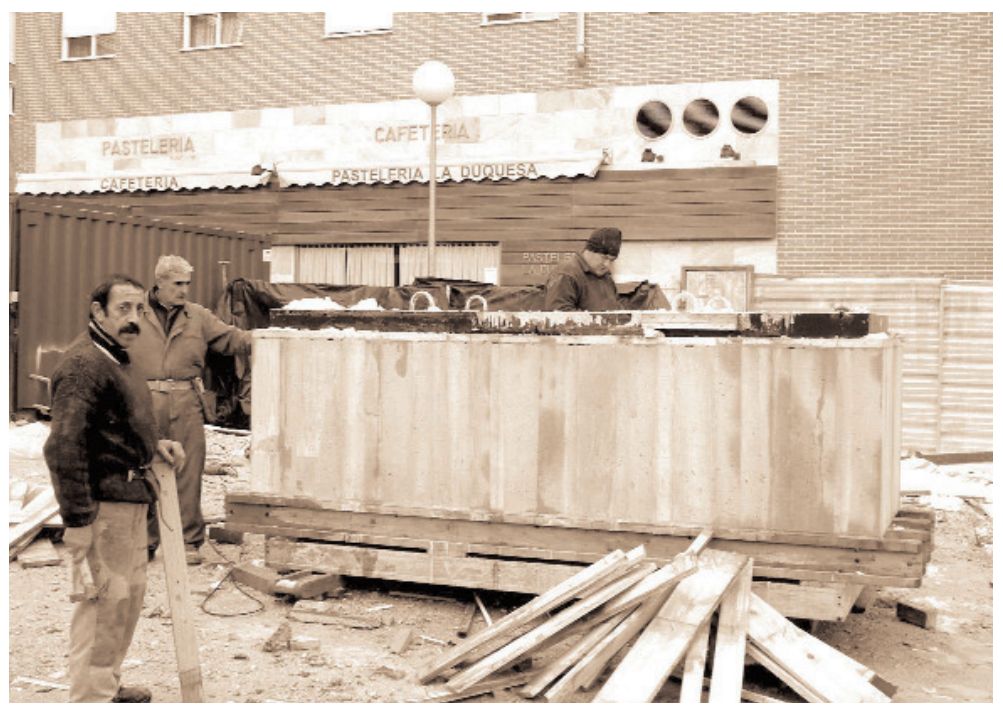

así como la colocación de la pila bautismal (Fig. 25).

Otros elementos exteriores, como las dos cruces y el campanario, fueron realizados en fundición de bronce. El campanario que traspasa la fachada del atrio tiene forma de yugo, y sirve de soporte a dos campanas que fueron recuperadas de una iglesia que fue desacralizada precisamente mientras se estaba construyendo ésta: la iglesia de Jesús y María, en el casco antiguo de Pamplona, que fue comprada por el Ayuntamiento al Arzobispado para convertirla en albergue de peregrinos. Estas campanas estaban abandonadas; pudimos rescatarlas y colocarlas en este edificio.

Voy a enseñar unas imágenes del estado final de la obra ya acabada. La iglesia se hace fuerte frente al entorno difícil del barrio. Frente a nuestra voluntad inicial de crear una gran plaza, las dos semiplazas fueron urbanizadas por los técnicos municipales. Nos hubiera gustado haber intervenido en el proyecto, pero reconocemos que se ha hecho con bastante dignidad. Todas las puertas de acceso al atrio pueden abrirse completamente. A nosotros nos gustaría que estuvieran siempre abiertas, tanto a un lado como a otro, para facilitar el tránsito por ellas, y que este espacio, al mismo tiempo que un espacio de ingreso a la iglesia, fuera un espacio de comunicación entre las dos plazas y entre los vecinos del barrio (Fig. 26).

$\mathrm{El}$ atrio es un espacio difícil de fotografiar porque es pequeño. Las fotos se hacen siempre con gran angular y deforman un poco la imagen, pero dan una cierta idea del espacio interior recoleto que quiere ser un primer punto de reunión dentro de esa secuencia de ingreso: desde la avenida San Jorge, ruidosa y transitada, a las dos semiplazas peatonales al lado del edificio, pasando por este espacio ya mas propio de la iglesia, para finalmente acceder desde él a la iglesia (Fig. 27).

En la nave principal, el volumen de la sacristía fue realizado con las mismas tablas de madera de pino teñido con el que se realizó el falso techo. Unos elementos colgantes procuran luz artificial por la noche. Era imposible que el efecto luminoso que se produce durante el día se reprodujera idénticamente durante la noche; por lo tanto, se buscó otro tipo de iluminación que también recreara el espacio con un cierto misterio e invitara a la meditación, al recogimiento, pero actuando de una manera inversa. La megafonía son unos elementos suspendidos que inicialmente pensábamos colocar en el techo, pero que los técnicos nos recomendaron bajar por razones acústicas. Una pequeña escalera de caracol situada al fondo de la nave sube al espacio del coro, que sirve también para el mantenimiento de la vidriera de alabastro. Hay una línea continua de luz que permite iluminar ese plano de alabastro por la noche, convirtiéndolo en un fanal de luz hacia el atrio (Fig. 28).

En la capilla de diario, el sagrario está situado en un 


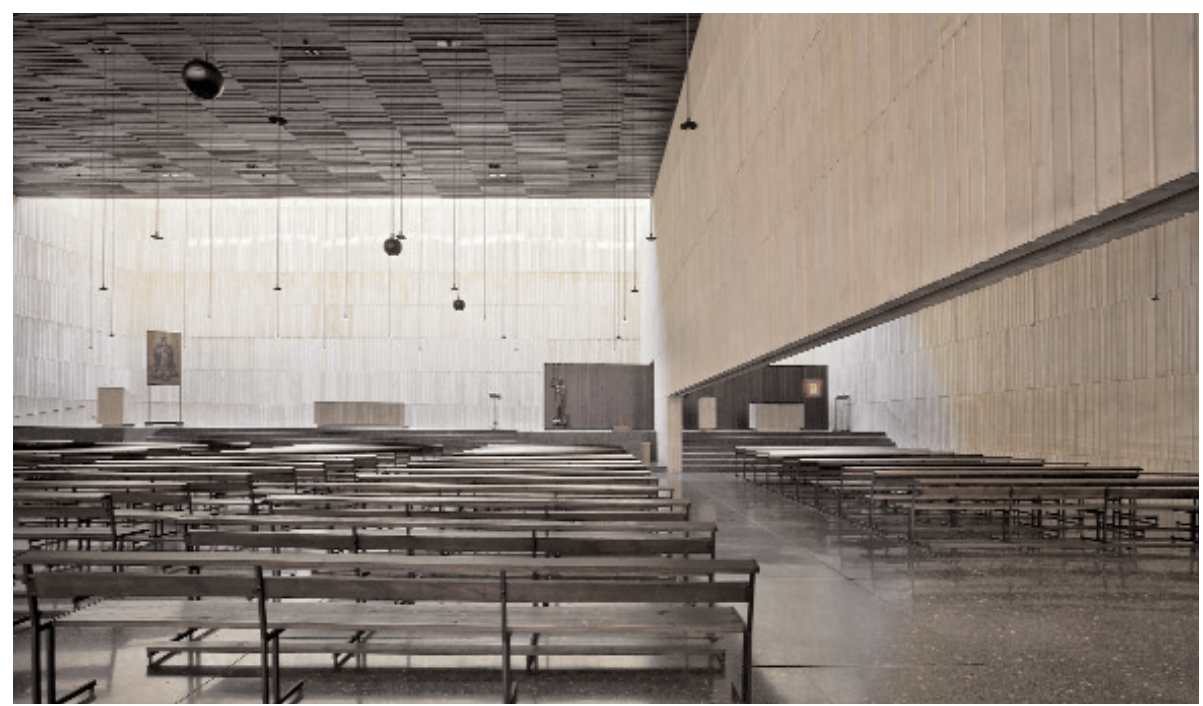

Fig. 28. La nave principal y la capilla eucarística o de diario (2008).

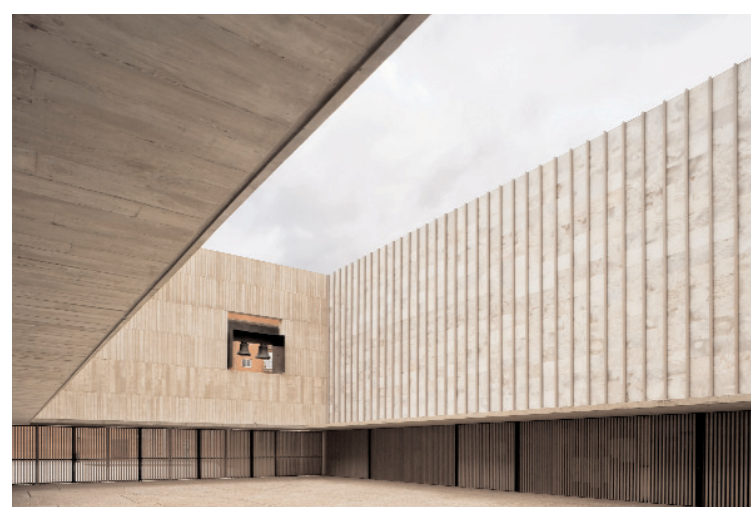

Fig. 27. El atrio terminado (2008).

Fig. 26. Fachada este de la iglesia, con las puertas cerradas o abiertas.

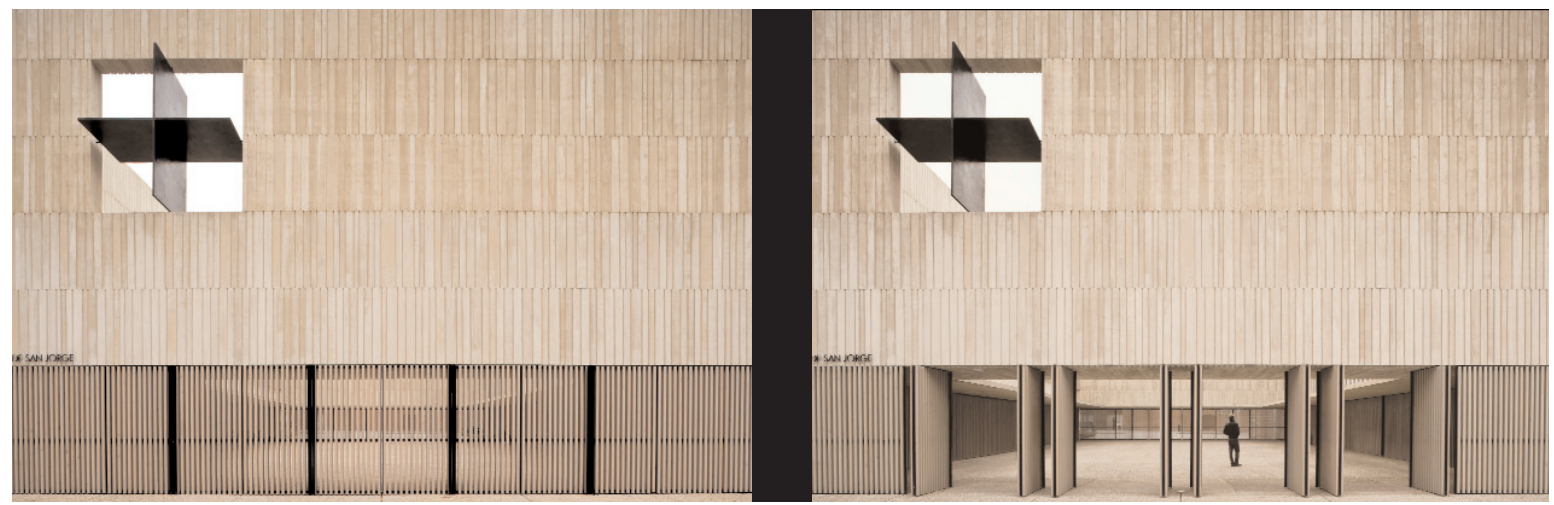




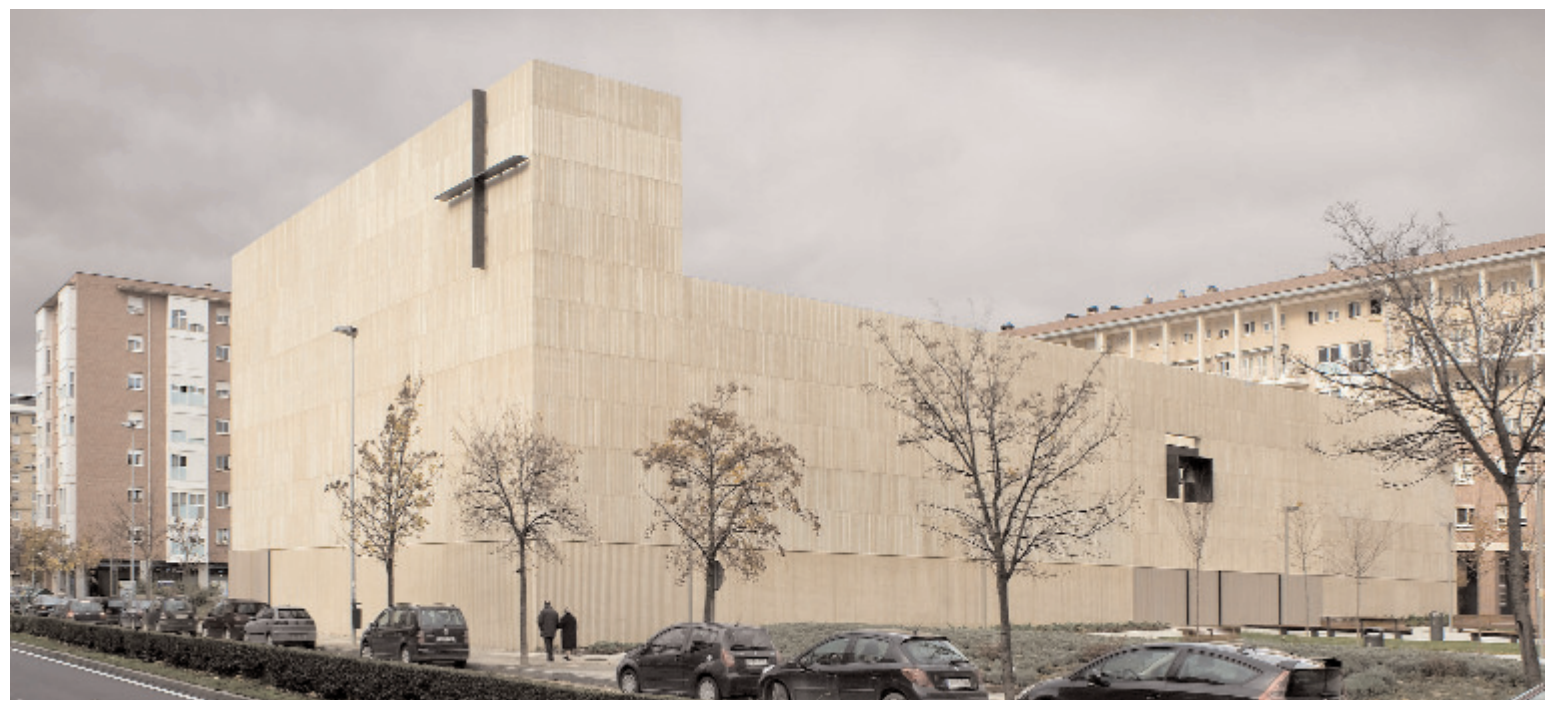

nicho iluminado de color rojo para indicar la presencia del Santísimo. La pila bautismal también fue realizada en hormigón. La Virgen, cedida por el Arzobispado, y una imagen de San Jorge que para nosotros no tenía valor artístico pero que provenía de la antigua iglesia, han quedado integradas en este volumen.

Finalmente, queremos agradecer el trabajo de todas las personas que han intervenido en esta obra. Nosotros simplemente somos la cabeza visible de un amplio equipo de colaboradores - arquitectos, ingenieros y aparejadores- que han trabajado con nosotros, amen de la empresa constructora, Construcciones VDR, que ha hecho una magnífica labor y a la que estamos muy agradecidos (Fig. 29).

\section{FICHA TÉCNICA}

Denominación: Iglesia y centro parroquial San Jorge. Pamplona Promotor: Arzobispado de Pamplona-Tudela

\section{EQUIPO REDACTOR}

Proyecto de arquitectura: Tabuenca \& Leache, arquitectos (Fernando Tabuenca González y Jesús Leache Resano)

Colaboradores: Alejandro Sánchez, Javier Zalacaín

Desarrollo de la estructura: Susana Iturralde

Mediciones y presupuesto: José Luis Sola Labari y A. Pérez Espinosa Estudio de Seguridad y Salud: J.L. Sola Labari y Arturo Pérez Espinosa Desarrollo de las instalaciones: GE \& Asoc. SL Ingenieros Consultores Fecha de inicio: Mayo 2005

\section{EQUIPO DE OBRA}

Dirección de obra: Tabuenca \& Leache, arquitectos

Dirección de ejecución: José Luis Sola Labari y Arturo Pérez Espinosa Dirección de Seguridad y Salud: J.L. Sola Labari y A. Pérez Espinosa Empresa constructora: Construcciones VDR Jefe de obra: Paula Martínez Custardoy

Fecha de fin de obra: Marzo 2008

Superficie: $2.746,24 \mathrm{~m} 2$ 